\title{
Population Density of Tomato leaf miner Tuta absoluta Meyrick (Lepidoptera:Gelechiidae) under plastic houses conditions (b)
}

\author{
${ }^{1}$ Lazgeen H. Assaf, ${ }^{2}$ Feyroz R. Hassan, ${ }^{2}$ Halgurd R. Ismael, ${ }^{1}$ Salah A. Saeed \\ ${ }^{I}$ General Directorate of Agriculture-Duhok, Duhok, ${ }^{2}$ Dept. of Plant Protection, School of Plant \\ Production, Faculty of Agriculture and Forestry, University of Duhok, Kurdistan Region, Iraq.
}

\begin{abstract}
The aim of this work was to investigate the population density and infestation percentage of Tuta absoluta on tomato crop Lycopersicum esculentum Mill under plastic houses conditions in two locations at Duhok province $\left(36^{\circ} 54^{\prime} N, 43^{\circ} 8^{\prime} E\right) /$ Kurdistan region/ northern of Iraq in 2012. The average number of mines/ leaflet and larvae/ leaf during the study season were 1.36 and 0.42 respectively. The results showed a significant differences in number of mines/leaflet and number of males/trap among the two locations. In spite of that the pest management strategies were weekly applied by farmers and based largely on chemical applications (Insecticide) which targeted to controlling T. absoluta and other lepidopteran pests (Noctuidae: Heliothinae), a high percentage of infestation was recorded in September as $100 \%$ and $72 \%$ for Summel and Zawita respectively. A maximum number of males/ trap/week was 56.66 recorded on 10/9/2012 in Summel .
\end{abstract}

Keywords: Tuta absoluta, population dynamics, Tomato, Kurdistan region-Iraq.

\section{Introduction}

Tomato (Lycopersicon esculentum) is one of the economic important crops of Iraq. It is consumed as fresh table tomato and as an essential raw material for a variety of food processing industries. According to Food and Agriculture Organization 2010, tomato was planted in highland in the world reached to 1.2 million hectare and in Iraq the planted area reached to 842.296 hectare. In Duhok province, more than 12000 hectare of land was planted with tomato in 2012 (General Directorate of Duhok Agriculture 2012).

Tomato production faces many problems from several causes such as seasonal weather, temperature, humidity, diseases and insect pests. There are several insect species feed on tomato for examples: thrips, whitefly, tomato fruitworm, leaf miner, leafhopper, aphid, mites and mealybug. Recently, the tomato borer, Tuta absoluta_ (Meyrik) (Lepidoptera:Gelechiidae ) is one of the most devastating pest of tomato crops in South America (Epp, 2010). After its initial detection in eastern Spain in 2006, its rapidly invaded various other European countries and spread through the Mediterranean basin (Desneux et al. 2010). Tomato borer $T$. absoluta_introduction history in Iraq is rather recent which was first detected in Autumn 2010 from sex pheromone traps installed in Rabia region, Nineveh province (Abdul-Razaq et. al. 2010 ). Since that time, this pest spread quickly in all tomato growing areas in Iraq, destroying entire open fields and tomato in plastic house. Ramireze et. al. (2010) reported that the damage by T. absoluta can reach to $100 \%$ in unprotect crops and it was considered in its region distribution area as a significant tomato insect pest (Leite et. al. 2010), due not only to the intensity of its attack but also to its occurrence during all crop cycle (Oliveira et. al. 2008). It can develop on other Solanaceous plants, like potato (Pereyra and Sanchez, 2006), eggplant and wild species (Garacia and Espul, 1982). Abbes and Chermiti, 2011 concerning the use of pheromone traps for pest monitoring, reported that the trap catches can be correlated with larval damage. In this way, the minimal amount of spraying required to control the pest population.

The aim of this work is to study the infestation level and development of T. absoluta population on tomato crops Lycopersicum esculentum Mill under plastic houses conditions in two sites at Duhok governorate during 2011- 2012 crop season .

\section{2-1: Study area}

\section{Material And Methods}

To carry out this work, four commercial plastic houses $\left(400 \mathrm{~m}^{2} /\right.$ each) located in two sites within Duhok governorate ( $36^{\circ} 54^{\prime} \mathrm{N}, 43^{\circ} 8^{\prime} \mathrm{E}$ ) as Zawita ( $855 \mathrm{~m}$ a.s.l. and $16 \mathrm{~km}$ far from Duhok centre) and Summel ( $473 \mathrm{~m}$ a.s.l and $16 \mathrm{~km}$ far from Duhok centre) were chosen. The average of temperature degree and relative humidity was obtained from Metrological Station of Duhok Governorate .

\section{2-2: Experiment procedure}

To study the infestation level and development of $T$. absoluta population on tomato crop Lycopersicum esculentum Mill, two methods were taken as follow: 


\section{1-leaves sampling for recording larvae and mines numbers:}

To calculate the larvae and mines number of $T$. absoluta, plastic houses were divided to four subarea approximately $100 \mathrm{~m}^{2} /$ each. Each subarea with a similar number of plants to ensure that all the area be represented in the samplings. Weekly sampling were carryout from May to September and in each plastic house 24 plants were randomly selected being six in each subarea. At each selected plant five leaflets were collected and individually packed in labelled plastic cans then transported to the laboratory.

At the laboratory, with aid of Binocular, each leaflets was examined and the number of mines and larvae per leaflet was registered (Leite et.al. 2001).

\section{2- Trapping methods for adult males harvesting :}

This experiment was conducted in the same plastic houses mentioned above. The adults of $T$. absoluta were monitored by using pheromone lure TUA-500. Three traps in each house were well positioned and installed $0.5 \mathrm{~m}$ above ground level. Sex pheromone capsules were renewed every four weeks and the number of captured individuals was recorded every week during study period from May to September 2011-2012 .

\section{Results And Discussion}

3-1: Leaves sampling for recording larvae and mines number

The data represented in table (1) showed that the general mean number of $T$. absoluta mines/leaflet was 1.32 and 1.39 for Zawita and Summel, respectively.

Table1: Mean mines, larvae number and the infestation percentage of leaves during the study season.

\begin{tabular}{|l|c|c|c|c|c|c|c|c|}
\hline \multirow{2}{*}{$\begin{array}{l}\text { Sample } \\
\text { sites }\end{array}$} & \multirow{2}{*}{$\begin{array}{l}\text { Average No. } \\
\text { mines/leaflet }\end{array}$} & \multirow{2}{*}{$\begin{array}{l}\text { Average No. } \\
\text { larvae/leaflet }\end{array}$} & \multirow{2}{*}{$\begin{array}{c}\text { Average No. } \\
\text { males/trap }\end{array}$} & \multicolumn{4}{|l|}{ Leaves Infestation Percentage \% } \\
\cline { 5 - 8 } & & & May & June & July & August & September \\
\hline Zawita & $1.32 \mathrm{~b}$ & $0.19 \mathrm{~b}$ & $13.15 \mathrm{~b}$ & 0 & $0 \mathrm{~b}$ & $44.8 \mathrm{a}$ & $57 \mathrm{~b}$ & $72.00 \mathrm{~b}$ \\
\hline Summel & $1.39 \mathrm{a}$ & $0.64 \mathrm{a}$ & $29.91 \mathrm{a}$ & 0 & $37 \mathrm{a}$ & $45.6 \mathrm{a}$ & $100 \mathrm{a}$ & $100 \mathrm{a}$ \\
\hline
\end{tabular}

Means followed by a common letter within the same Column are not significantly different at the $5 \%$ level by DMRT

According to fig. (1), the number of mines/leaflet was initially low in May and June and increasing during August and September to reach a maximum of 5.10 and 4.37 mines on 10/9/2012 for Summel and Zawita, respectively.

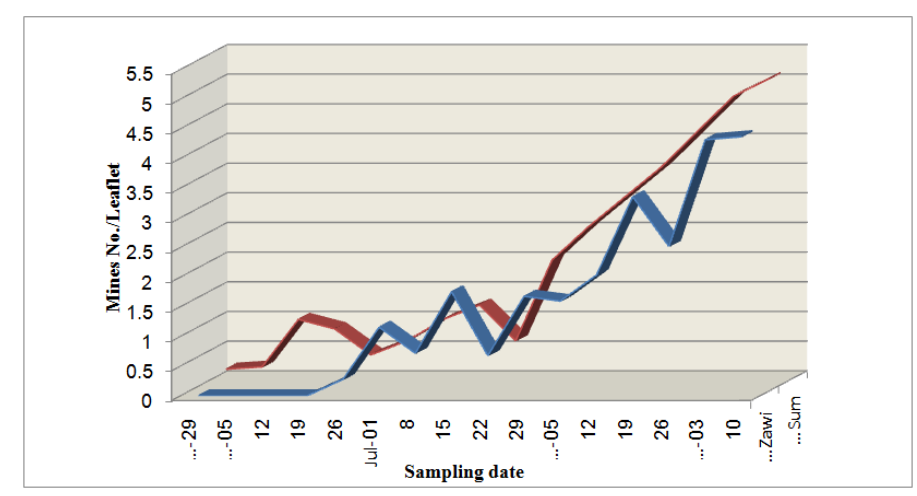

Fig.1: Average number of T. absoluta mines/leaflet on tomato leaves in two locations

The maximum number of leaf mines was closely related to the density of $T$. absoluta larvae, that the damage caused by larvae on tomato leaves in two locations led to high density of mines rising up to an average of 1.86 mine/ leaflet starting from the late of July (fig.1). Increasing of the larvae number on leaves caused a high infestation rate reached to $100 \%$ and $72 \%$ in September for Summel and Zawita (tab1), respectively.

Allache and Demnati (2012) mentioned that in Biskra (Algeria), during the first phonologic stages of the crop, tomato plants are free from attack of T. absoluta.Harizanova et.al.(2009) pointed that the leaves were the most heavily damaged plant parts with an average of 9.42 and 8.75 mines per leaflet on the middle and upper layer of the canopy respectively, followed by the fruits.

Statistical analysis showed a significant differences in leaf mines caused by T. absoluta larvae among the two locations (tab. 1). It could be concluded that in Zawita the mean number of mines, the infestation rate 
and the number of larvae per mine was the lowest because it was located in mountainous location which was characterized by $(855 \mathrm{~m})$ above sea level and the low temperature degree. This result agreed with Lacordaire and Feuvrier (2010) who reported that the number of T. absoluta was influenced perhaps by abiotic factors like temperature, insecticide application and by biotic factors i.e absence of natural enemies.

The average number of larvae/ leaflet (tab. 1) was 0.64 and 0.19 for Summel, and Zawita, respectively. It was frequent according to Lacordaire and Feuvrier (2010) that the larvae of T. absoluta left their galleries and reinstalled in another leaflet or leaf as suggested by Torres et.al. (2001), which also added that this low number might be due to insecticide applications which limited the development of the larvae.

\section{3-2 Trapping methods for adult males harvesting :}

According to fig. 2, the average number of adults male captured by pheromone traps was variable during study period in the two sites. T. absoluta was present from early June until September in Summel, while in Zawita it was noted from mid July to September. For the two sites, the adults captured increased towards the end of plant cycle. In Summel it was relatively low in June with an average of 14.73 adults/ trap/week (fig. 2) and their number became relatively high, as their attack became intense towards the end of crop cycle that reached to a maximum of 56.66 adults/trap/week on 10/9/2012 (fig.3). An increase in temperature was detected at this time in the year.

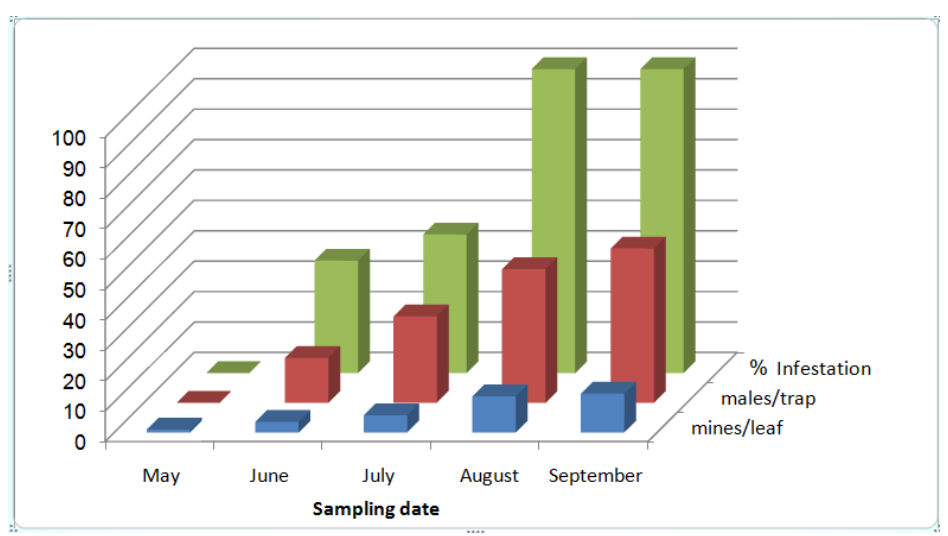

Fig(2): Monthly average numbers of mines/leaf, males/trap and infestation \% in Summel

These results agreed with Nannini et.al. (2010), who mentioned that in Southern Sardinia (Italy), the highest number of moths caught in traps were in September-October. These results also matched with those found by Miranda et.al. (1998) and Lacordaire and Feuvrier (2010), who underlined the occurrence and increase in leaf miner captures during the crop season. During this gradual increase, each renewal of the capsules was often followed by an increase in the number of trapped adults.

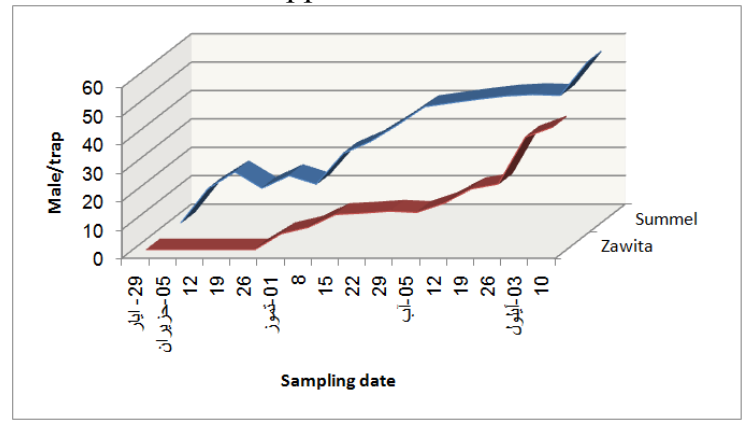

Fig.3: Weekly average number of T. absoluta trapped males of two locations

The average number of captured males/week was 29.91 and 13.15 in Summel and Zawita, respectively (tab. 1). Although the number of adults captured in Summel was more abundant than that in Zawita and there was a significant differences between these two population, the figure of the evaluation of mass trapping in Zawita shows a similar shape of that in Summel (fig. 3). Indeed after 5.75 males caught on 1/7/2012, the number of trapped males continued to increase speedily to exceed 43.25 on 10/9/2012.

Analysis showed a significant positive correlation between the number of mines /leaf and the number of trapped males in both Summel and Zawita as ( $\mathrm{r}=0.750, \mathrm{r}=0.819)$, respectively (fig. 2 and 4). However, simple correlation between infestation rate and the number of catches in sex phermone traps was also positive significant in two regions ( Summel, $r=0.649$ and Zawita, $r=0.801$ ). These results agreed with Abbes and 
Chermiti (2011) and Cely et.al. (2010) who reported that the number of leaves and leaflets were differentially affected by the densities of $T$. absoluta infestation $(\mathrm{p} \leq 0.05)$

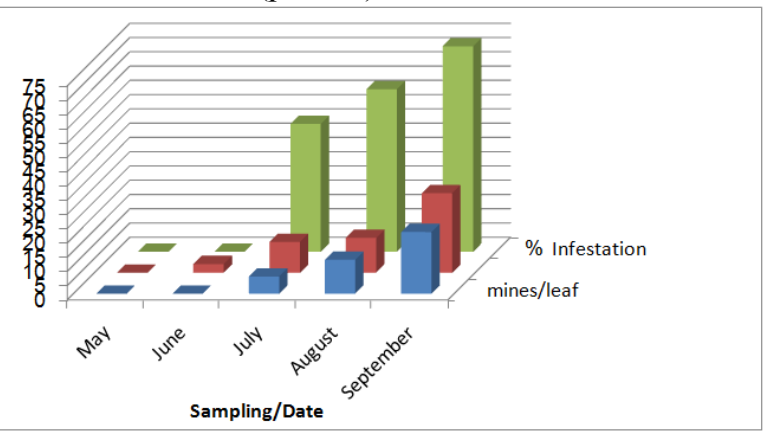

Fig(4): Monthly average numbers of mines/leaf, males/trap and infestation \% in Zawita

Some authors recommend 30 trapped males per trap per week to start chemical curative measures. Monitoring is very important in IPM programs; it allows the detection of the early infestations. Sprayings of chemicals based on data from pheromones traps are usually more effective in controlling first attacks and avoiding the rapid colonization of the crop. This can significantly reduce the number of sprayed insecticides, and preserve natural enemies of the pest. For instance, Merid bug Nesidiocoris tenuis, an efficient natural enemy of T. absoluta, especially in open field (Abbes and Chermiti 2010), was very influenced by chemicals in Brazil where pest control was mainly based on heavy insecticide sprays reaching 36 treatments per season (Filho et.al. 2000).

\section{References}

[1]. EPPO. 2010. List of biological control agents widely used in the EPPO region. http:// archives.eppo.org/ EPPOStandards/ biocontrol web/bio list.htm.

[2]. Desneux N, Wajnberg E, Wyckhuys KAG, Burgio G, Arpaia S, Narva'ez-Vasquez CA, Gonza'lez-Cabrera J, Catala'n Ruescas D, Tabone E, Frandon J, Pizzol J, Poncet C, Cabello T \& Urbaneja A (2010). Biological invasion of European tomato crops by Tuta absoluta: ecology, geographic expansion and prospects for biological control. Journal of Pest Science, 83, 1-19.

[3]. Abdul Razzak AS, Al-Yasiri II, Fadhil HQ (2010) First record of tomato borer (tomato moth) Tuta absoluta (Meyrick) (Lepidoptera: Gelechiidae) on tomato crop in Iraq, 2010. Arab and Near East Plant Protection Newsletter no. 51 , p 31.

[4]. Ramirez, L, Ramirez, N., Fuentes, L.S., Jiminez, J. and Hernandez-Fernandez, J. 2010. Estandarización de un bioensayo y evaluación preliminar de tres formulaciones comerciales de Bacillus thuringiensis sobre Tuta absoluta (Meyrick) (Lepidoptera: Gelechiidae). Rev. Colomb. Biotecnol., 12(1), 12-21.

[5]. Leite, G.L.D., Picanço, M., Guedes, R.N.C. and Zanuncio, J.C. 2001. Role of plant age in the resistance of Lycopersicum hirsu tum f. glabratum to the tomato leafminer Tuta absoluta (Lepidoptera: Gelichiidae). Sci. Hort., 89, 103-113.

[6]. Oliveira, A.C.R.D., Veloso, V.D.R.S., Barros, R.G., Fernandes, P.M. and Souza, E.R.B.D. 2008. Captura de Tuta absoluta (Meyrick) (Lepidoptera: Gelichiidae) com armadilha luminosa na cultura do tomateiro tutrado. Pesqui. Agropecu. Trop., 38(3), 153157.

[7]. Pereyra, P.C. and Sanchez, N. (2006). Effect of two Solanaceous plants on developmental and population parameters of the tomato leafminer, Tuta absoluta (Meyrick) (Lepidoptera: Gelechiidae). Neotropical Entomology 35: 671-676.

[8]. Garcia, M.F. and Espul, J.C. 1982. Bioecologia de la polilla del tomae (Scrobipalpula absoluta) en Mendoza, Republica Argentina. Rev. Invest. Agropecuarias INT A, 17, 135-146.

[9]. Abbes, K. and Chermiti B. 2011. Comparison of two Marks of Sex Pheromone Dispensers Commercialized in Tunisia for their Efficiency to Monitor and to Control by Mass-Trapping Tuta absoluta under Greenhouses. Tunisian Journal of Plant Protection Vol. 6, No. 2, 2011.

[10]. Allache F and Demnati F 2012. Population Changes of Tuta absoluta (Mey.) (Lepidoptera, Gelichiidae): A New Introduced Tomato Crop Pest at Biskra in Algeria. Jordan Journal of Agricultural Sciences, Volume 8, No.3 2012.

[11]. Harizanova V., Stoeva A. and Mohamedova M. 2009. Tomato leaf miner, Tuta absoluta (Povolny) (Lepidoptera: Gelechiidae) first record in Bulgaria. Agricultural science and technology vol. 1, No 3, pp 95 - 98, 2009.

[12]. Lacordaire A.I. and Feuvrier, E.2010. Tomate, traquer Tuta absoluta. Phytoma, 632, 40-44.

[13]. Torres, J.B., C.A. Faria, W.S. Evangelista \& D. Pratissoli. 2001. Within-plant distribution of the leaf miner Tuta absoluta (Meyrick) immatures in processing tomatoes, with notes on plant phenology. Int. J. Pest Manag. 47: 173-178.

[14]. Nannini M., Atzori F., Foddi F., Pisci R. and Sanna F. 2010. A survey of Tuta absoluta (Meyrick) (Lepidoptera: Gelichiidae) outbreaks in tomato greenhouses in southern Sardinia (Italy). International Symposium on Plant Protection

[15]. Miranda, M.M.M., Picanço, M.C., Zanuncio, J.C and Guedes, R.N.C. 1998. Ecological life table of Tuta absoluta (Meyrick) (Lepidoptera: Gelichiidae). Biocont. Sci. and Tech., 8, 597-606.

[16]. Anonymous, 2009. http://www. koppert.com/ products/monitoring/productds-monitoring/detail/pherodis-2/.

[17]. Filho, M.M., Vilela, E.F., Jhan, J.M., Attygalle, A., Svatos, A., and Meinwald, J. 2000. Initial studies of mating disruption of the tomato moth Tuta absoluta (Lepidoptera: Gelechiidae) using synthetic sex phermone. J. Braz. Chem. Soc. 11:621-628. 